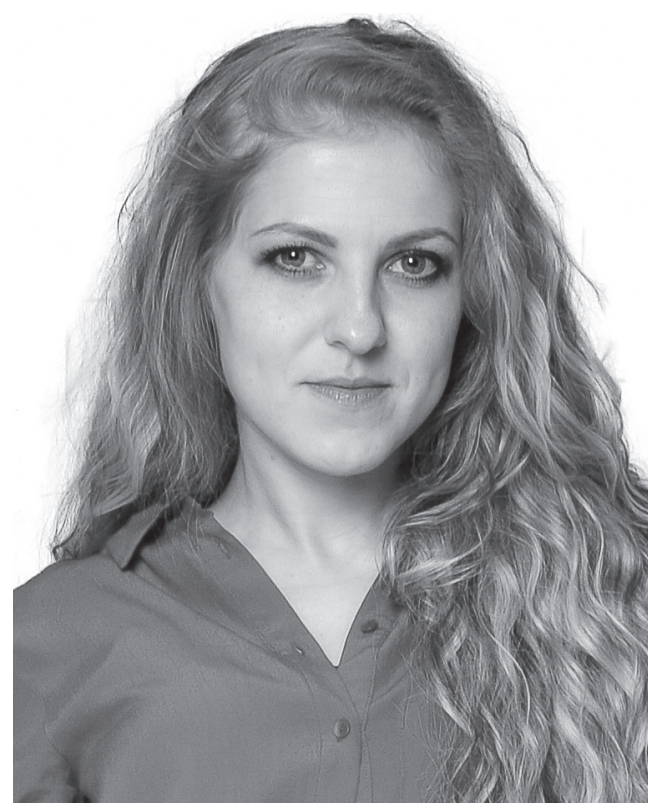

UDC: 351.77

DOI: https://doi.org/10.32689/2617-

2224-2019-17-2-78-84

\section{Karlash Viktoria Victorovna,} applicant of the National University of Civil Defense of Ukraine, Educational, Scientific and Production Center of the National University of Civil Defense of Ukraine, 61024, Kharkov, Str. Lermontovska, 28, tel.: (057) 70734 20,e-mail:vk.lug85@gmail.com

ORCID: 0000-0002-8092-1189

Карлаш Вікторія Вікторівна, здобувач Національного університету цивільного захисту України, Навчально-науково-виробничий центр Національного університету иивільного захисту України, 61024, м. Харків, вул. Лермонтовська, 28, тел.: (057) 70734 20, e-mail:vk.lug85@ gmail.com

ORCID: 0000-0002-8092-1189

Карлаш Виктория Викторовна,

соискатель Национального университета гражданской защиты Украины, Уиебнонаучно-производственныий центр Национального университета гражданской защиты Украинь, 61024, г. Харьков, ул. Лермонтовская, 28, тел.: (057) 70734 20, е-таіl: vk.lug85@gmail.com

ORCID: 0000-0002-8092-1189

\title{
PROBLEMS OF GOVERNMENT REGULATION IN THE HEALTH OF UKRAINE
}

Abstract. The article reveals a relevant topic in the health care system of Ukraine, which seems to be the peculiarities of the state regulation of the healthcare sphere. First of all, the author of the article determines the main directions of the modern development of the healthcare sphere. So the article says that today there is a process of reforming in the field of health care, which involves the achievement of effective ways of developing the provision of public health care.

The author notes the main legislative and legal features of the regulation of health care, which are aimed at determining the directions and priorities of health policy in Ukraine. The article states that there are two directions in the system of public health administration, which imply the provision of an effective legal framework in economic and social relations in the context of the industry reform process.

Particular attention is paid to one of the important areas of regulation of the health care system, which involves resolving issues of public law regulation in 
order to achieve a high level of provision of the population with guaranteed realization of the rights of citizens in this area.

Further, the author points to the need for the development of state regulation in relation to the creation of legislation and legal support on the basis of a unified methodological framework of regulatory legal acts.

The article reveals the main objectives of state regulation in the field of health. The author notes that the first concerns the issues of regulating the means and methods of ensuring the operation of an effective health care system. The second relates to the improvement of governance mechanisms in the field of medical services relations. In this regard, both of these tasks have their own range of problems that are to be solved as part of the solution of issues of state regulation in the field of health care in Ukraine.

Summarizing, the author determines the future prospects of the study in studying the problem of standardization of the health care industry.

Keywords: health protection, health care system, government regulation, medical services market.

\section{ПРОБЛЕМИ ДЕРЖАВНОГО РЕГУЛЮВАННЯ У СФЕРІ ОХОРОНИ ЗДОРОВ'Я УКРАЇНИ}

Анотація. Розкрито актуальну тему в системі охорони здоров’я України, передбачену особливостями державного регулювання сфери охорони здоров'я та основні напрями сучасного розвитку сфери охорони здоров'я. Розглянуто процес реформування сфери охорони здоров'я, яким передбачено досягнення ефективних шляхів розвитку забезпечення охорони здоров'я населення.

Зазначено основні законодавчі та правові особливості регулювання сфери охорони здоров'я, спрямовані на визначення напрямів та пріоритетів політики охорони здоров’я України. Наголошено, що в системі державного управління охорони здоров'я є два напрями, які передбачають забезпечення ефективної правової основи в економічних та соціальних відносинах в умовах процесу реформування галузі.

Особлива увага надається одному з важливих напрямів регулювання системи охорони здоров’я, який передбачає вирішення питань публічно-правового регулювання з метою досягнення високого рівня забезпечення населення гарантованою реалізацією прав громадян у цій сфері.

Ідеться про необхідність розвитку державного регулювання щодо створення законодавства та правового забезпечення на основі єдиної методологічної бази нормативно-правових актів.

Розкрито основні завдання державного регулювання у сфері охорони здоров'я. Зазначено, що перше стосується питань регулювання засобів і методів забезпечення діяльності ефективної системи охорони здоров’я, друге - удосконалення механізмів управління у сфері відносин медичних послуг. У зв’язку з цим обидва завдання мають певне коло проблем, які під- 
лягають вирішенню в межах досягнення високого рівня державного регулювання у сфері охорони здоров'я України.

Визначено подальші перспективи дослідження у вивченні проблеми стандартизації галузі охорони здоров'я.

Ключові слова: охорона здоров'я, система охорони здоров'я, державне регулювання, ринок медичних послуг.

\section{ПРОБЛЕМЫ ГОСУДАРСТВЕННОГО РЕГУЛИРОВАНИЯ В СФЕРЕ ЗДРАВООХРАНЕНИЯ УКРАИНЫ}

Аннотация. Раскрывается актуальная тема в системе здравоохранения Украины, которая представляется особенностями государственного регулирования сферы здравоохранения. В первую очередь автор статьи определяет основные направления современного развития сферы здравоохранения. Рассмотрен процесс реформирования в сфере здравоохранения, который предполагает достижение эффективных путей развития обеспечения охраны здоровья населения.

Отмечены основные законодательные и правовые особенности регулирования сферы здравоохранения, которые направлены на определение направлений и приоритетов политики здравоохранения Украины. Речь идет о том, что в системе государственного управления здравоохранения имеется два направления, которые предполагают обеспечение эффективной правовой основы в экономических и социальных отношениях в условиях процесса реформирования отрасли.

Особое внимание уделяется одному из важных направлений регулирования системы охраны здоровья, которое предполагает решение вопросов публично-правового регулирования с целью достижения высокого уровня обеспечения населения гарантированной реализацией прав граждан в данной сфере.

Указывается на необходимости развития государственного регулирования по отношению к созданию законодательства и правового обеспечения на основе единой методологической базы нормативно-правовых актов.

Раскрыты основные задачи государственного регулирования в сфере охраны здоровья. Отмечено, что первое касается вопросов регулирования средств и методов обеспечения деятельности эффективной системы здравоохранения, второе - усовершенствования механизмов управления в сфере отношений медицинских услуг. В связи с этим обе эти задачи имеют свой круг проблем, которые подлежат решению в рамках решения вопросов государственного регулирования в сфере здравоохранения Украины.

Определены дальнейшие перспективы исследования в изучении проблемы стандартизации отрасли здравоохранения.

Ключевые слова: охрана здоровья, система здравоохранения, государственное регулирование, рынок медицинских услуг. 
Problem statement. Today, in the development of the domestic health care system there is a reform process, caused by existing problems, including low level of socio-economic efficiency and legal regulation of activity. At the same time, there is a tendency indicating that in the process of reform, the national health system undergoes significant organizational, legal and substantive changes. First of all, this relates to the creation of a legislative framework for health reform, aimed at decentralizing the state system of health care and health care management.

However, regardless of changes, the functioning of the health care system has a number of difficulties, among which we can highlight the decline in the level and quality of medical care for the population, the increase in the number of socially dangerous diseases, the increase in mortality and the decline in fertility, which in turn leads to negative natural population growth, insufficient level of financing, etc.

Many of these problems are determined by the lack of an integrated approach to healthcare due to deformation of the system of medical prophylaxis, as well as a decrease in the availability of qualified health care for a large part of the population. The important point here is that the health care system directly depends on the implementation of a clear and consistent state policy on public health, backed up by the legal, organizational and financial sector. From the correct definition of the direction and priorities of such a policy, together with the results of the work of the public administration, the effectiveness of the health care system as a whole depends. In such conditions, the study of the main problems in the system of state regulation in the field of health care is of great importance.

Analysis of recent publications on research issues. Today there are a number of publications devoted to the problem of improving the health care system of Ukraine. Among them one can distinguish V. M. Lekhan, V. M. Rudo, Yu. V. Voronenko, O. G. Sheker et al., Which indicate the need for changes in the organizational structure, forms of management and current legislation.

In addition, a number of scientific publications related to the formation and development of the right to health, among which work by T. A. Zanfirova and Ya. F. Radish, point out that in our country there have always been attempts to make society responsible for the state of health, thus speaking about the need to use such experience in building public health management system.

Purpose of the article. The purpose of the article is to identify the main problems that are related to the current situation in the system of state regulation in the healthcare sector of Ukraine, as well as the definition of general directions for their solution.

Presenting the main material of research. Healthcare is one of the priority areas of the state's activity, which deals with the formation of health care policy in Ukraine and helps to ensure its implementation. In addition, the state ensures citizens' rights to health care and the implementation of state social development programs.

Regarding health regulation, it involves two interrelated areas. The first is issued in the legal regulation of the organization of health care, and the second is the legal regulation of the 
implementation of the human right to health. In connection with this, the main function of state regulation of health care is the creation of an effective legal framework for economic relations that will take into account the conditions for reforming the industry, the excessive function of the state to provide free medical care, and also provide an opportunity to achieve sustainability in the system of ensuring the right to health [1].

A special place in the regulation of the health care system in our country is given to various targeted programs. Such target programs are a set of measures aimed at achieving concrete actions, thus allowing more effectively to socially significant problems in protecting and restoring the health of citizens. The main purpose of such target problems is to meet certain needs of the population and to improve the efficiency of medical organizations.

It is the society that perceives health care as an integral part of the quality of life, which has an important impact on the economic development of the state, contributing to the reproduction and quality of labor resources and, thus, creates the basis for further socioeconomic growth. In this regard, one of the important problems in regulating the health system is the search for an effective model of the national health system that will be adequate to the current realities of society. First of all, this concerns the fact that today's domestic health care system does not allow to realize the necessary principles of marketing relations in the unformed market of medical services [2].

In our opinion, one of the most important directions in this system is the strengthening and expansion of publiclaw regulation in the field of health care, which, in this case, should be aimed at the realization of the rights of every citizen of our country to receive a guaranteed level of health care.

However, today in the Ukrainian legislation there is no holistic mechanism of state regulation of market economic relations, except for certain regulatory and legal mechanisms regarding the use by the state of a regulator [3]. Note that such means are licensing, the order of regulation of prices and tariffs, the establishment of special economic regimes, etc. In this connection, there is a need to address the problem of the lack of the ability to achieve its functional purpose specified by the regulatory tool in the case when other regulators will operate autonomously. Here we mean that in order to solve the problem, it is important to achieve a simultaneous settlement of all funds.

In this regard, we assume that state regulation of the development of healthcare should be directed to the creation of promising legislation and regulatory support, which will contribute to the effective achievement of public health. Thus, it also implies the achievement of a qualitative unity of the methodological basis of normative legal acts. In this context, support for national economic interests, national economic security and public health is at the forefront. All of these factors are universal, but the implementation of health policy implies not only specific types of factors, but also takes into account common measures for them [4].

In our opinion, among the tasks of state regulation in the field of health 
are two important aspects. The first relates to the fact that regulatory measures must ensure the solving of political tasks, while the other provides for the improvement of management mechanisms. The same should be taken into account in the political aspect, which is to achieve social and economic goals. Its nature appears in the normative character, which is based on the system of values adopted in society, which relate to certain political tasks and interests of society.

It is important to note that sociopolitical health problems in all modern countries are the same. Therefore, among them, one can distinguish the following:

- Equal access to health care;

- achieving social solidarity by providing health care through a national health service or social health insurance system;

- Earning profit through the provision of financially sound healthcare costs;

- achievement of healthy conditions of the environment, safe working conditions, food and drinking water;

- The necessary level of awareness and education of the population on health issues [5].

Another aspect of management is the mechanisms of public health management, which have a mixed nature, which show the peculiarities of the relationship between the providers of health services. Such measures are aimed at achieving the effective and rational use of human and material resources, and are primarily technical in nature. The direction of regulation of such mechanisms should solve the following problems:
- Quality and efficiency of medical services;

- access of patients to services, taking into account the introduction of appropriate tax policy;

- the appropriate level of behavior of suppliers and payers, the activities of doctors and other health professionals;

- Establishing a balanced market for medicines by controlling profits and determining price policy [6].

Thus, state regulation of activities in the field of health care should act as a state's activity aimed at ensuring the interests of the population and the state itself through the application of predominantly administrative methods of influencing the behavior of business entities. Moreover, the legal basis of state regulation will be in the management, control and application of administrative and economic sanctions.

Conclusions and prospects for further research. Thus, in the course of independence in our country a national legal basis has been formed in the sphere of health care, which today can not fully meet the modern needs of society. At the same time, the decision of the problems connected with the state regulation in the field of health care in Ukraine can be called an important direction in management and organizational medical activities.

In addition, one of the pressing problems in regulating the health sector today is the problem of the standardization of the industry, as the issues of the level of licensing of medical services, the level of accreditation, the need for medical care, the economic level, which determine the need for medical procedures, remain unresolved and the level of effectiveness of both the effectiveness 
and quality of the provision of medical care.

All this suggests that today there is a need for a comprehensive study of the legal regulation of medical activity, first of all it concerns the development of a new regulatory framework that will act as an instrument for implementing state policy and improving the management of health care in Ukraine as a whole.

\section{REFERENCES}

1. Voronenko Yu. V. (2013). Normativno-pravovoe obespechenie semejnoj mediciny $\mathrm{v}$ svete reformy zdravoohraneniya Ukrainy [Regulatory support of family medicine in the light of health care reform in Ukraine], Health Suspension. Vol. 2 (1), p. 1522.

2. Radysh J. (2008). Gosudarstvennoe regulirovanie obshestvennyh otnoshenij $\mathrm{v}$ oblasti ohrany zdorovya Ukrainy: istoricheskie i pravovye aspekty [State regulation of public relations in the field of health care in Ukraine: historical and legal aspects], Medical Law. 2, p. 26-37.

3. Gladun Z. S. (2005). Derzhavna politika ohoroni zdorov'ya $\mathrm{v}$ Ukrayini (administrativno-pravovi problemi formuvannya i realizaciyi) [State policy of health care in Ukraine (administrative and legal problems of formation and implementation)], Ternopil, Ukraine.

4. Moskalenko V. F. (2008). Principi organizaciyi optimalnoyi modeli sistemi ohoroni zdorov'ya: ukrayinskij kontekst [Principles of organization of an optimal model of the health care system: Ukrainian context], Kiev, Ukraine.

5. Rudiy V. M. (2015). Zakonodavche zabezpechennya reformi sistemi ohoroni zdorov'ya v Ukrayini [Legislative support for the reform of health care system in Ukraine], Kiev, Ukraine.

6. Lekhan V. M., Rudoh V. M. (2005). Osnovni shlyahi podalshogo rozvitku sistemi ohoroni zdorov'ya v Ukrayini. spilnij zvit [The main ways of further development of the health care system in Ukraine. joint report], Kiev, Ukraine.

\section{СПИСОК ВИКОРИСТАНИХ ДЖЕРЕЛ}

1. Вороненко Ю. В. Нормативно-правовое обеспечение семейной медицины в свете реформы здравоохранения Украины / Ю. В. Вороненко, О. Г. Шекера // Здоров'я суспільства. - 2013. - Т. 2, № 1. - С. 15-22.

2. Радыш Я. Государственное регулирование общественных отношений в области охраны здоровья Украины: исторические и правовые аспекты / Я. Радыш, Н. Мезенцева, Л. Бурав-Леви // Медицинское право. 2008. - № 2. - C. 26-37.

3. Гладун 3. С. Державна політика охорони здоров'я в Україні (адміністративно-правові проблеми формування і реалізаціі): монографія Тернопіль: Економічна думка, 2005. $-460 \mathrm{c}$.

4. Москаленко В. Ф. Принципи організації оптимальної моделі системи охорони здоров'я: український контекст: монографія / В. Ф. Москаленко. - К.: Книга плюс, 2008. - 320 с.

5. Рудий В. М. Законодавче забезпечення реформи системи охорони здоров’я в Україні. - К.: Сфера, 2015. $272 \mathrm{c}$.

6. Основні шляхи подальшого розвитку системи охорони здоров'я в Україні. спільний звіт / За заг. ред. В. М. Лехан, В. М. Рудого. - К.: Видво Раєвського, 2005. - 168 с. 